\title{
INTERPRETIVE SUBJECTIVATION ANALYSIS - A CRITICAL PERSPECTIVE ON THE DISCURSIVE SITUATEDNESS OF HUMAN SUBJECTIVITIES
}

\author{
SAŠA BOSANČIĆ ${ }^{1}$ \\ ${ }^{1}$ University of Augsburg, Universitaetsstrasse 10, 86156 Augsburg, Germany. ORCID: 0000-0001-5640- \\ 5400, Email: sasa.bosancic@phil.uni-augsburg.de
}

ABSTRACT: One of the developments based on the approach of Berger and Luckmann focuses on the analysis of discourses and subjectivation processes. The Interpretive Subjectivation Analysis (ISA) takes up these developments in order to establish a research perspective on the decentered subject that combines the theories of the Interpretive Paradigm of Sociology and the post-structuralist concepts of subjectivation as established in Judith Butler's and Michel Foucault's work. This paper outlines a qualitative methodological framework to analyze processes of subjectivation by including and relating empirical data on different levels. In order to show how this type of research can broaden the perspective on human subjectivities, the article discusses different empirical studies that focus on questions of inequality and marginalization. KEYWORDS: Interpretive Paradigm, Sociology of Knowledge, subjectification/ subjectivation, discourses, subjectivities, qualitative methods, decentered subject

\section{INTERPRETIVE SUBJECTIVATION ANALYSIS - A CRITICAL PERSPECTIVE ON THE DISCURSIVE SITUATEDNESS OF HUMAN SUBJECTIVITIES}

The Sociology of Knowledge in the tradition of Berger and Luckmann (1991 [1966]) has inspired and stimulated various theoretical and methodological developments and numerous empirical studies of the Social Construction of Reality (Pfadenhauer and Knoblauch 2019). Based on this tradition, the Interpretive Subjectivation Analysis (Bosančić 2017, 2018a, 2018b) links social constructivist and post-structuralist thinking in order to analyze how the embodied, living and speaking individual is constituted by and situated in symbolic and material orders. This research program addresses the classical sociological question of the interconnectedness of society and individuals or, as it has been reframed in different approaches, as the interrelatedness of subjective 
and objective realities, structure and agency, micro- and macro-level, system and lifeworld and so on. In post-Marxist and post-structuralist thinking, Louis Althusser and Michel Foucault had a major impact on conceptualizing subjectivation in a similar way as Max Weber for instance. Weber's (2002 [1904/1905]) early sociological study on the 'Spirit of Capitalism' showed how people's everyday practices were influenced by religious salvation messages and how this entanglement of cultural and discursive 'callings' on the one hand and people's self-relations and practices on the other hand pushed forward a capitalist formation of society. Althusser (2001 [1971]) also refers to a kind of entanglement as his concept of interpellation shows how ideological state apparatuses call upon subjects and shape them as individuals with coherent identities. In his historical and empirical studies, Foucault takes up these thoughts and analyzes the way subjects are constituted by powerful discourses and dispositifs.

Following all these traditions, subjectivation (sometimes also referred to as subjectification) can be understood as an interrelatedness or entanglement of normative subject orders and subjective self-relations, or, as Foucault puts it,

What are the games of truth by which man proposes to think his own nature when he perceives himself to be mad; when he considers himself to be ill; when he conceives of himself as a living, speaking, laboring being; when he judges and punishes himself as a criminal? (Foucault 1990b: 7)

The Foucauldian concept of subjectivation had a strong impact on the debates about the decentered subject in Cultural, Postcolonial or Gender Studies as well as various other research fields. On the one hand, theoretical debates were initiated in these contexts, for instance in Spivak's (1998) or Butler's (1997) works. On the other hand, the Governmentality Studies continued Foucault's empirical work that he outlined in his lectures on the genealogy of the neoliberal formation of society and the entrepreneurial self. ${ }^{1}$ Theoretically and empirically, both perspectives on subjectivation hardly refer to the sociological tradition on the duality of structures (Giddens 1984) or the concept of the Self (Mead 1972 [1934]). Also, these traditions neither have an elaborate methodological standpoint for instructing empirical studies, nor do they adopt qualitative research methods. Therefore, most of the empirical work somehow follows Butler's or Foucault's ideas without (explicitly) specifying how the theoretical framework was implemented in concrete research practices. The other way around, sociological tradition hardly takes into consideration the debates about subjectivation. Instead, sociologists for the most part continue to speak about selves and subjectivities, individuals and actions. However, if they do include the Foucauldian concepts of power relations and subjects, ${ }^{2}$ their heuristic concepts for doing empirical research are more focused on the constitution of symbolic orders than on the intertwining of normative subject positions and subjective self-relations.

In this paper, the Interpretive Subjectivation Analysis (ISA) will be discussed as a

'Cf. Foucault (2007, 2008), Bröckling (2015), Burchell, Gordon and Miller (1991), Dean (1999), Lemke (2001) and Rose (2007)

E.g. Adele Clarke's Situational Analyses (2005) or Reiner Keller's Sociology of Knowledge Approach to Discourse (Keller 2011, 2013; Keller, Hordnidge and Schünemann 2018). possible link between elaborate methodologies and methods of the Interpretive Paradigm of Sociology on the one hand and post-structuralist approaches of subjectivation that do not reflect their methodological groundings and methods on the othe hand. Therefore, it is necessary to discuss how Foucault's and Butler's most influential works on subjectivation can be integrated in an interpretive sociological tradition. The first chapter therefore focuses on the questions of agency and structure in order to lay the methodological foundation of the ISA. The second chapter takes up these theoretical assumptions and develops heuristic tools to instruct empirical research on subjectivation processes. Finally, the third section presents two empirical case studies to show how ISA is used in the implementation of empirical research projects.

\section{THE METHODOLOGICAL IMPLICATIONS OF THE ISA}

Foucault deals with questions of how subjects are aligned with discursively constituted orders of knowledge and how individuals are normalized in the contested and powerful 'games of truth' (Foucault 1990a, 1990b). However, the individuals addressed that are interpellated by normative symbolic orders are not determined by themselves but they are more or less free, as Foucault often emphasizes (in his work). For example, Foucault argues that there would be no need for technologies of power if people were not able to act differently than the governmental, disciplinary or biopolitical power mechanisms are pushing them to act: "Power is exercised only over free subjects, and only insofar as they are "free"” (Foucault 1994: 342). Foucault is therefore often misunderstood as having proclaimed the 'death of the subject' like Jaques Lacan and other post-structural thinkers. On the contrary, Foucault's concepts were closer to the Interpretative Paradigm of Sociology than to (post-)structuralist 'theories without a subject'. As Keller (2018) shows, Foucault analyzed discourses as regulated statement practices that deal with objects and co-constitute the objects of which they speak. In his historical and empirical studies, Foucault analyzed the 'games of truth' in which differently situated actors struggled about the legitimate interpretation of reality, e.g. by discursively constructing the differentiation between criminal and conform subjects (Foucault 1995), rational and insane subjects (Foucault 2003) or subjects with a normal or a deviant sexuality (Foucault 1990a). According to Keller (2018: 16), this is very similar to the pragmatist and symbolic-interactionist tradition of analyzing the definition of the situation, a starting point of sociological thinking as defined by William I. Thomas and Dorothy Thomas in the 1920s. Thus, both traditions focus on how reality is constructed in powerful 'games of truth' by actors who are co-constituted by these games of truth. As Keller puts it:

Conflicts over the definition of situations likewise occur in quite different areas and arenas. In fact, they are a basic feature of the collective human struggle with the world, its existence and resistances, with unfolding events, catastrophes, action choices, evaluations and all kinds of corresponding ways of problem solving. Events, problematisations and their actors who are engaged in the politics of knowledge and knowing, that is, in meaning making/world making: these are the core drivers of discursive struggles (and social transformations). (Keller 2018: 
17)

Despite these similarities, Foucault was not concerned with (the) questions of agency in his genealogical perspective on the normative formation of subjects. I.e., in contrast to the interpretive sociological tradition, he refuses to make any anthropological statements on the 'human condition' and to elaborate his concept of a subject beyond the assumption that subjects are always shaped by symbolic orders and mechanisms of power in specific historical contexts. Judith Butler takes up Foucault's thoughts on power, discourses and subjectivation, but just as in the sociological tradition, she is also not only interested in the genesis of the 'Technologies of the Self' (Foucault 1988, 1991b) and the changing regimes of subject formation. Butler also wants to know how power works and enfolds on the 'inside' of the subject. Butler therefore criticizes Foucault and argues that the explanation of subject formation would need a psychoanalytical framework. She argues that "the formation of the subject cannot fully be thought (...) without recourse to a paradoxically enabling set of grounding constraints" (Butler 1997: 87). These grounding constraints consist of two processes of foreclosure: first, the necessity to repress the fact that love is constituted in relations of dependence; second, the enforced foreclosure of homosexuality (ibid.: 135). These losses constitute the psyche of the subject and as they take place in a pre-reflexive phase of childhood, the individual is not aware of these losses and therefore unable to grieve. According to Butler (1997: 167), these unconscious foreclosures constitute a melancholic subject that is "haunted by an inassimilable remainder" (ibid.: 29) and hence, subjects are bound to seek recognition. This concept of psyche as the 'inner space' of a subject is problematic for various reasons.

First, psychoanalytical concepts like melancholia are highly speculative terms and, from a Foucauldian perspective, such terms should rather be subject to a discourse analysis than be used as explanations for the basic formation of subjects. Or, as Charles W. Mills already pointed out in his analysis of vocabularies of motive, "There is no need to invoke 'psychological' terms like 'desire' or 'wish' as explanatory since they themselves must be explained socially” (Mills 1940: 905).

Second, from a genealogical perspective, it is unclear whether the melancholic subject is only a way of forming the subjects in a specific historic (period) and spatial context or whether Butler somehow assumes that this way of constituting the/a subject is universal. Third, from the pragmatist perspective of William James (2003 [1907]), it could be asked if certain theoretical assumptions make a difference while doing empirical research. If one thinks of a researcher who conducts qualitative interviews for instance and his findings show three or more different ways of how people react in a certain situation or his/her findings reveal different ways of how people narrate their identities and relate to different discourses while positioning themselves. Since individuals are not determined by symbolic orders, these kinds of differences will al ways appear in empirical data and the theoretical assumption of a basic desire for recognition cannot explain the various empirical differences because all subjects share this desire. In other words, the desire for recognition may explain why people want to adopt specific subject positions and identities in general, but it cannot explain why people choose specific subject positions over others, for instance, why some people adopt right-wing and others adopt left-wing identities. Further, it cannot be explained either why the adoption of a certain subject position is performed in a more or less broad variety.

So even if Butler's criticism of Foucault's concept of a subject that does not elaborate human agency is justified, I am arguing in favor of a more careful use of explanatory concepts of how subject are shaped. In order to conduct empirical research on subjectivation processes and regarding the pitfalls of Butler's concepts, I suggest that instead of invoking psychological or psychoanalytical terms it is more useful to adopt Butler's (2011: 60) concepts of performativity and iterability she conceptualizes following and criticizing Austin, Searle and Derrida. In this respect, performativity means that subject norms need to be repeated in order to exist, but every repetition or citation is not only a rearticulation of a norm but always a resignification as every citation of a norm inevitably comes along with a deferral (ibid.: 70). In other words, norms need to be repeated, but every repetition takes place under different tempora and spatial conditions, and therefore, every repetition is a resignification, i.e. a - however slight - shift or deferral of nthe norm. Moreover, norms do not have an origin but exist only as a practice of repeating, which is another reason why repetition is always resignification. In contrast to post-structural theories that assume that norms or structures change on the long run without the agency of social actors, but because of inevitable deferrals, Butler adheres to a concept of human agency. She puts forward that the necessity of repletion of subject norms opens up possibilities for resignification(s). Still, living and embodied individuals have to occupy these spaces opened up due to necessary repetition. In her examples, Butler (2011: 84) demonstrates for instance that gender norms are not only changed through iterability processes without a subject, but through the performances of Drag-Kings or Drag-Queens who actively challenge the heterosexual matrix and generate other subject norms and positions.

This concept of agency is compatible with Foucault on the one hand who also assumes that the subject is formed in submission but still has the agency to resignificate norms or to resist interpellations. On the other hand, Butler's concept of agency is also highly compatible with the tradition of the Interpretative Paradigm of Sociology. George Herbert Mead (1972: 174-175), for instance, conceptualizes the Self as consisting of the two inseparable instances of the I and the Me. The Me is constituted through the internalization of norms, and the I is the present part of our Self we are only aware of when we act. However, when we start to think about our Self, the I can only be ac cessed through the Me, i.e. we are never fully aware of our Self since we always depend on symbolic orders like discourses and vocabularies of motive in these self-reflexive processes. So the I is a kind of (a) 'black box' similar to the 'inassimilable remainder' in Butler's concept. In contrast to Butler, the I is not conceptualized as a psyche with certain desires but as the active part of the organism that forces and enables us to act more or less freely in the context of symbolic orders that are not created freely. Berger and Luckmann (1991), who refer to George Herbert Mead and Alfred Schütz, also conceptualize the subject as not being determined but situated and socialised within historically and socially developed universes of discourses (Mead 1972) or stocks 
of knowledge (Schütz and Luckmann 1973) which have to be interpreted. Hence, the basic assumption of the ISA is that human individuals are able to interpret symbolic orders as Butler is assuming with the concept of resignification on the one hand. On the other hand, human actors are forced to interpret symbolic orders because these orders do not speak for themselves but need to be constantly performed by actors and therefore make interpretations necessary (Reichertz 2013). According to Butler, this necessity results from the need of repetition; in the interpretive sociological tradition it is assumed that symbolic orders can be understood as some kind of 'instructions' (Giddens 1984) that have to be specified in concrete historical and spatial situations. Ultimately, and despite all the differences, Mead's, Butler's and Foucault's perspectives on subjects and subjectivation processes are to the extent that they assume that human individuals and this kind of subjective 'inner space' are instances of (partly communicatively structured) self-reflexivity which is situated in and constituted by 'outer' symbolic orders, materialities as well as time and space relations. Therefore, the methodological standpoint of the ISA refers to these traditions and conceptualizes subjectivation as a process during which subject norms are constructed and human individuals are addressed by these normative symbolic orders. The two key questions of the ISA is how these non-determining processes of being addressed and of shaping (or not shaping) one's self according to the discursive interpellations and instructions are taking place and how they can be investigated empirically. To this end, the ISA proposes heuristic tools that will be discussed in the next chapter.

\section{THE ANALYTIC TOOLKIT OF THE ISA}

First of all, the emergence and transformation of subject norms as well as their processing and circulation must be clarified. One way to do so is to analyze which actors get into positions where they can legitimately speak and are thus involved in the discursive struggles about the definitions of reality. It is also important to ask which actors are excluded and which voices are silenced or not heard at all. For this purpose, the ISA encompasses the concept of speaker positions which is developed in the Sociology of Knowledge Approach to Discourse following Foucault. Speaker positions are "depict positions of legitimate speech acts within discourses which can be taken on and interpreted by social actors under specific conditions (...) as role players." (Keller 2011: 55). How do they become speakers though?

This might happen by their being socialised within a particular universe of discourse (such as mathematics or psychological expertise) for example through university education and careers and institutional role taking. This might happen also by just starting to engage for organisational or private reasons with an issue of public concern (like poverty, human rights, or ecological transformation). (Keller 2018: 35)

(The) speaker positions are contested, and different speakers struggle to authorize themselves to participate in the 'games of truth'. In these struggles, they use different vocabularies of motive, story lines or interpretive schemes and frames to establish their "politics of knowledge" (ibid., pp. 32-34). In these discursive struggles, subject positions are constructed as well:

Subject positions/Identity offerings depict positioning processes and 'patterns of subjectivation' which are generated in discourses and which refer to (fields of) addressees. Technologies of the self are understood as exemplary elaborate, applicable and available instructions for subjectivation. (Keller 2011: 55)

Such discursively constructed subject positions unfold their power effects by making certain self-relations appear desirable on the one hand and, often simultaneously, by constituting negative examples that are stigmatized or denied recognition. A well known subject position is the 'entrepreneurial self' which comes along with the stigmatized and marginalized negative subject position of 'the unemployed person'. These negative subject positions often unfold instructions of how the deviant subjects should be educated, disciplined, punished or excluded (Keller 2018: 36). However, these discursively constructed subject positions and the interpretive schemes, frames, storylines and dispositifs which accompany them or in which they are situated should not be confused with how the living, speaking and embodied human individuals are reacting to them. This can manifest itself in the entire spectrum of possible forms of human reaction: from the attempt to take up the subject positions affirmatively, to misinterpret them, to appropriate them partially, to subvert them and so on. In order to analyze these processes, the ISA develops the concept of self-positioning (Bosančić 2014, 2017). Self-positioning is a permanent, precarious, tentative, changeable, dynamic and ongoing process that takes place when people are addressed and identified with subject positions and other 'truths' circulating in discourses and within dispositifs. The foundations for this concept of self-positioning are derived from Mead's (1972), Goffman's (1961, 1971, 1974, 1986, 2013) and Strauss' (1959) works on the Self and on the non-essentialist concept of identity. According to their theoretical conceptions and especially following Goffman, people are permanently positioned and identified according to socially constructed facts, such as race, class and gender, or to personal facts, such as their looks or the stories they tell about themselves. These processes take place in life-world contexts, in organizational settings and dispositive arrangements and they are often mediated through discourses. Therefore, people are constantly confronted with normative expectations and thus, self-positioning is to be understood as a process inevitably running along due to the nature of social contexts and situations, without requiring reflected attention to the subject positions and norms. It is possible, for instance, that an unemployed person is 'activated' by public employment agencies by more or less forcing him/her to be self-responsible and to subject his/her personal goals to the demands of the labor market. During this process, neither the unemployed person nor the public representative profiling the unemployed person has to be aware that he or she is being addressed with the subject position of the entrepreneurial self. By being profiled and treated according to the neoliberal labor market regime, the subject position of the entrepreneurial self is implemented even if none of the actors is aware of that. Nevertheless, in such a context of subjectivation, the researcher can make plausible that, on the one hand, 
certain subject positions can be implemented through the dispositive arrangement and by tools of activation that are applied. On the other hand, self-positioning processes of the unemployed person can only be explained adequately if the researcher analyzes them as reactions to the interpellation by the subject position. In contrast, it is also possible that processes of self-positioning are highly reflexive, for instance, when people decide to challenge the demands of the subject position as a 'consumer'. In the minimalist movement, for instance, people are highly aware of being positioned in a certain way and they try out new ways of self-positioning, e.g. by living in relatively self-sufficient communities or by moving into tiny homes. By doing so, they may also even generate new subject positions through their collective activities on the internet or through political activism. Besides clarifying that self-positioning can take place on a continuum between highly reflective and non-reflective processes, the latter example also shows that speaking positions, subject positions and self-positioning are intertwined. People are not necessarily only addressed by subject positions that other actors in speaking positions have constructed and legitimized. Rather, people addressed in certain ways can subvert this way of being addressed and contest the dominant subject positions by creating new ones through their collective effort to gain a speaker position

To sum it up, subject positions do not determine the self-positioning processes. Thus, self-positioning is more or less reflexive and more or less creative engagement with subject positions. As Goffman $(1961,2013)$ has shown, self-positioning is always accompanied by processes of distance-making and deviation. These deviations inevitably unfold as a result of the aforementioned necessity to interpret the subject positions and to specify them in concrete situations as subject positions are complex, overstraining, ambiguous and even contradictory. As Berger and Luckmann (1991) as well as Schütz and Luckmann (1973) have shown, people are situated in different positions within the social structure as well as in different life-world contexts where they are confronted with various subject positions and other 'truths' constructed discursively. They have developed various biographical relevancies and act upon situational demands in changing institutional and organizational settings. For this reason, self-positioning is always a process of resignification, and creative deviation processes are consequently not a unusual, but rather the regular way of self-positioning. In turn, this does not mean that these processes of deviation and resignification inevitably result in transformations of the subject positions. In other words, although each adaption and appropriation of a subject position means deviation, not every single resignification results in a change of hegemonic subject positions and discourses, as implied by the assumptions of iterability and performativity (cf. chapter 2). There may be similar deviations in self-positioning processes of different individuals, but only if these typical ways of self-positioning stimulate collective actions and people try to get in speaking positions, transformations of subject positions or the emergence of new ones may take place.

The ISA thus uses various analytic actor categories as sensitizing concepts (Blumer 1954) to empirically examine how power relations unfold, i.e. who is able to participate in what way in the discursive 'truth production' by gaining a speaking position and what kinds of effects on the self-positioning processes unfold. The questions of agency are understood as empirical questions by using qualitative methods to investigate how power relations are affecting people in specific subjectivation contexts. The ISA thus focuses on asking which resources are available to the people addressed by normative symbolic orders and which situations of interpellation are perceived and felt to be restrictive as well as to what extent. This methodological framework necessarily needs to take into account two levels of empirical data. On one side, researchers need to examine the context of the interpellation, i.e. the subject positions and the specific contexts of subjectivation, with methods of discourse analysis or ethnographic research designs for instance. On the other side, data about self-positioning processes must be collected, e.g. by conducting qualitative interviews or through a participant observation. Finally, these two levels of data have to be related to each other to analyze if and how the subject positions, discourses or dispositifs unfold power effects on the self-positioning processes. The following chapter will demonstrate how these conceptual strategies of the ISA are implemented.

\section{CASE STUDIES WITH ISA}

In order to analyze the relationship between speaker positions, subject positions and self-positioning processes, it is necessary to investigate empirically both the symbolic orders and 'games of truth' with their subject norms as well as the ways these normative orders are adopted by living, acting and embodied human beings. Only through this methodological basic principle can it be ensured that researchers do not deductively conclude that certain discursive positions have an effect on the interview narratives or that certain observations in the field are power effects of subject positions and vice versa. The methodological rule therefore says that both the self-positioning processes and the respective subject norms as well as their circulation and the contexts of subjectivation should be examined, because only the knowledge of both levels can give a plausible explanation about the relations between subject positions and modes of self-positioning. This will be illustrated by two empirical studies in this chapter. The first one is a study by (Bosančić 2014) that deals with low-skilled working-class men, while the second study by Lisa Pfahl (2011) is on the self-positioning processes of students with 'learning difficulties' in the context of 'special needs schools'

\subsection{Low-skilled workers}

Bosančić (2014) conducted a study on low-skilled workers, ${ }^{3}$ i.e. workers who are marginalized due to the neoliberal transformation of the labor market when jobs in the industrial sector were 'outsourced' to low-wage countries or eliminated due to technological developments. Mostly male working-class members have lost their previous social status with the start of globalization processes. Not only did they lose their

By 'semi-skilled' it is meant that it just takes a few hours or days to learn the necessary job skills. The category was used as an analytical category in Goffman’s (2013: 83) sense for the purpose of the study and did not intend to qualify the worker's qualifications in any way. 
more or less secure employment positions, they were also marginalized due to the loss of power of the unions which had been able to provide positive and proud subject positions for the workers. These marginalization processes were accompanied by a new hegemonic discourse of the knowledge-based society in which only high skilled workers are valuable. By a meta-analysis of discourse based studies on work and economy, ${ }^{4}$ three subject positions were reconstructed: the entrepreneurial self, the creative self and the flexible self. These dominant subject positions do not provide any opportunities for semi-skilled workers to relate to themselves in a positive way since they are not able to fulfill the requirements constituted by the subject positions. The question guiding the qualitative interviews with low-skilled male workers was about how the economic and discursive marginalization influenced their self-positioning processes.

One outcome from the interviews was that some of workers could still adapt the subject position of the flexible self. The kind of impact or influence that is referred to can be seen in the following statement:

I can do almost everything that's needed. I am responsible for the incoming goods as well as for the outgoing goods. I check what is needed for the production department and do many more things. And if one of my colleagues is ill, I'll just jump in and take his place - that's no problem at all. For me it's normal, I can work everywhere in the warehouse. Most of my colleagues have their own sector - I mean, that is also a lot of work, too. But for me, there is not just one thing, I can work anywhere in the logistics department. Ingoing goods, outgoing goods, processing orders, packaging, just everything. (Lothar, 48 years old, in: Bosančić 2014)

Lothar, who has been working in the same company in the industrial sector for 15 years, and the other workers interviewed spoke about their special ability to do all the jobs in their working section. They also pointed out that they could adapt to new tasks quickly and this was the reason why 'the boss' or the company needed them. This way of self-positioning implies that the workers see themselves as capable of doing many different jobs, of quickly adapting to new demands, of working extra hours and so on - and these are the skills that are highlighted in the discourses about the flexible self. This interpretation becomes more evident when taking into account the statements of workers who did the same jobs and explained how boring their job was or that no special skills were needed to fulfil the tasks. Hence, it is clear that the workers' explanations are not just reactions to the actual conditions of the workplace, but they are mediated through discourses. The findings show that one group of workers only focused on their family lives, their house and their backyard garden and led a secluded life without any interests other than their close social environment. Their interpretation of the workplace is more or less indifferent. The other group of workers who regard themselves as flexible is more open to the demands of the world at large, e.g. these workers are active in unions or follow the news. Therefore, this group has more resources to adopt to dominant discourses and to position themselves as flexible

${ }^{4}$ For instance Bröckling (2015) or Boltanski and Chiapello (2005). (weather or not they had the skills they were attributing to themselves). Taking into account that all the workers have seen many workmates lose their jobs or be replaced by temporary workers with lower wages, this way of self-positioning could be interpreted as a fictional security strategy, meaning that the self-attribution to be flexible empowers them to some degree so they can feel more secure not to lose their job(s).

\subsection{Students with 'learning disabilities'}

Lisa Pfahl (2011) examines modes of subjectivation in so-called 'special needs schools' in Germany, a type of school that focuses on the idea of 'healing' emerging at the interface of education and health care and that trains children and adolescents with behavioral problems or learning difficulties. The term 'special needs' is ascribed to certain pupils who require special support and are therefore taught separately from pupils from regular schools. In a first step, Pfahl uses the Sociology of Knowledge Approach to Discourse (Keller 2013) to investigate the knowledge production of the 'special needs pedagogy', a subdiscipline of educational science. Pfahl examines the mos important scientific journal of the professional association of special needs teachers. ${ }^{5}$ Pfahl's findings show that the segregation of pupils is the result of constructing knowledge in the field of special education, and the symbolic construction of 'special pupils' is a result of these powerful knowledge practices. The typical diagnosis of 'learning disability' is not identified as a constraint, but as a power technique seeking to generate acceptance by parents and children about the need for special educational support. Thus, separation and the symbolic positioning at the lower end of the educational hierarchy are legitimized with allegedly objective testing procedures. While at the beginning of the 20th century, the subject position of morally neglected 'poverty-sick' children appeared in discourses, this (subject position) has changed especially since the 1970s, when special education started to increasingly incorporate medical, biological and psychological knowledge in the course of the professionalization of the field. Since then, the subject position of 'students with learning disabilities' has become dominant. The development of learning difficulties is regarded as a disability and as a permanent impairment. Therefore, the 'special needs school' is conceived as a 'protected place' where students with learning disabilities are not confronted with labor market needs seeing the students' limited autonomy and learning abilities.

After analyzing the discursively constructed subject positions implemented in everyday teaching practices in special needs schools, Pfahl conducted qualitative interviews with pupils of these schools. Pfahl questions pupils that have been offered an apprenticeship because she wants to analyze how the 'successful ones' (very few pupils of special needs schools can be integrated into the job market to this extent) manage the transition from the 'protected place' to the labor market. One of the interviewees is 21-year-old Barbara who started school at the age of seven and attended a special needs school for ten years. After her time at the special needs school and a subsequent rehabilitation program, she completed an inter-company training course

${ }^{5}$ See also Pfahl and Powell (2011) 
to become a housekeeper. She states in the interview:

I want to start working after my apprenticeship. And I hope they won't think: 'Oh, she's from a special needs school, she can't make it here' or something like that. If the employers are normal and reasonable they won't care about that. And I did an internship so I have proven that I can do it - that's what should matter. But even if they accept me I'll still think to myself 'Do they really accept me?' Or do they just think 'ok, we'll take her because she's from a special needs school'. You know, like they just accept me in order not to hurt me or something. (Interview with Barbara, Pfahl 2011: 178)

The passage as well as the entire interview illustrate Barbara's contradictory self-positioning which can be interpreted as a precarious distinction from the subject position of the special pupil with learning disabilities. On the one hand, Barbara repeatedly distinguishes herself from the 'protective space', i.e. the special educationa measures; she contrasts this with the unprotected 'normality' of a 'real' workplace. Her self-normalization is thus achieved by rejecting the label 'special pupil' or 'being learning disabled'. On the other hand, these subject positions still make her feel insecure during the transition from a training place to a regular employment. She is not sure whether she will be accepted because of her vocational skills and competences or if work will still be a 'protected place'. Barbara clearly shows her fear of discrimination ("because I come from such a school") and her hope to escape it (those who are "normal and reasonable" will "not care"). She fears, however, that the employers will assume that she is not able to perform adequately due to her low qualification and her having attended a special needs school. For Barbara, successful integration into the labor market is ultimately no proof of her skills. On the contrary, the risk of being recognized only in a socially deprived position and not as a competent person ultimately means that the subject position of the 'pupil with learning disabilities' continues to have an effect on her self-relations despite her attempted rejection of the subject position.

The relationship between subject positions and self-positioning in the interview with Jenny is similar to Barbara's with regard to the restrictions and fears of discrimination. Jenny is also 21 years old and she attended a special school starting at the age of nine. After having finished school, she completed a job-coaching project and a two-year training as an infant care assistant. However, she did not find a job and had been unemployed for 18 months at the time of the interview. Prior to the following interview passage, she talks in detail about the testing procedures of the doctors and psychologists who identified her 'learning disability' and then continues with the following story:

This was so typical, I have to go to a special needs school and that was it for me. Ok, then, I thought I'll just have to make the best of it. And I never had to repea a year in school! I think I was even allowed to skip some courses, at an earlier stage. But I am not sure. Yes. But I never repeated a year. That would have been really, really terrible for me. Repeating a year in special needs school? No way. And I always had the best grades, I have to admit, honestly. (Interview with Jen- ny, Pfahl 2011: 141)

In contrast to Barbara, Jenny’s self-positioning can be interpreted as an ambivalent adaptation of the subject position of the 'special pupil with learning disabilities'. On the one hand, she accepts the transfer to the special needs school and does not in any way question the testing methods she previously talked about. Since Jenny is aware of the discriminatory attributions by the subject position of a special needs pupil, however, she applies different normalization strategies in the sense of Goffman's stigma management. Her self-positioning could be specified as different but equal, i.e. her normalization works through accepting the label 'learning disability', and at the same time, she is regaining autonomy by affirmatively adopting the meritocratic principle. Jenny distinguishes herself from the other special pupils by highlighting her special abilities, while at the same time being afraid of the comparison with persons of a higher status. However, Jenny's willingness to perform does not lead to an integration into the labor market. She accepts this failure by legitimizing the meritocratic principle and argues that her special school certificate is inferior. The acceptance of the subject position of the 'learning-disabled pupil' ultimately makes her lower her own ambitions, by which she also wants to protect herself from further disappointments in searching for a job.

The third way of self-positioning shows that there is a wide range of possible reactions when being addressed with a certain subject position. At the time of the interview, Nico was 19 years old and one of very few special needs school pupils who could start a regular vocational training immediately after having finished school. In the following interview passage, Nico describes his experiences in the vocational school:

First year apprentice, we had English lessons. And if I would have gotten a grade for it, I would have become a bad grade and failed. Because I didn't know anything before. And they practically started right away on a the level of super intelligent. Not like with the special needs students, but with super intelligent. They couldn't take any consideration for me. The others were in grammar school, comprehensive school, secondary school, whatever. And I came just now from the totally low special school. And we did not have real English lessons. And then I found a way, a small gap (...). I went to my English teacher and said: I come from a special needs school, please take that into account and she immediately took it into account. She immediately understood and said 'You won't get a grade, we will just note that you have successfully attended English lessons.' (Interview with Nico, Pfahl 2011: 187)

In this as well as other passages of the interview, it becomes apparent that Nico more or less subverts the subject position of the special needs student to his own advantage. He is able to ask for special treatment for himself, but he does not justify it with a special need for support but with his lack of education and knowledge he is not responsible for. Altogether, Nico, just like the other special needs pupils, is aware of his discreditable stigma as a result of having attended a special needs school. He is engaged in impression management (Goffman) to the extent that he largely conceals his school background, but then does reveal it with regard to certain performance 
expectations of teachers in order to compensate for the disadvantages experienced. Ultimately, Nico rejects the classification as 'learning disabled' and criticizes the disadvantages associated with special schooling.

Finally, Pfahl's empirical study impressively proves the power effects of the subject position of the 'learning disabled student', because even in Nico's subversion of the subject position the effectiveness of the subject position becomes evident. The students question themselves continually about their 'disability', and they remain permanently imprisoned in their attempt to normalize themselves. Moreover, they are affectively bound to the label 'learning disabled'. As the empirical data also shows, the subject position is nevertheless not determining, even if the scope of adaption and subversion is very limited and the special pupils only have few resources to reject the discriminatory subject positions. This is partly due to the economic marginalization of the group of special needs students which is assigned an inferior social status.

\section{CONCLUSION}

The research perspective of the Interpretive Subjectivation Analysis (ISA) is combing social constructivist and post-structuralist theories of the decentered subject to develop a methodological framework for analyzing subjectivation processes. The main argument in this paper is that such a methodological framework requires examining the relations between normative subject positons and the self-positioning processes of human actors. Otherwise, it is not possible to analyze discursive power effects on the one hand, or which technologies of the self are effectively opposing which mechanisms of power and how normative symbolic orders can be transformed collectively on the other hand. If, for example, only self-positioning processes in interview data are analyzed, it remains unclear whether and how specific subject positons were appropriated or undermined, if the researcher cannot account for the respective normative orders that unfold the assumed effects of power. Conversely, the analysis of discourses and governmental strategies does not provide any information as to whether these interpellations do have any power effects on the living and embodied subjects. Therefore, subject norms and human self-relations must both be examined empirically, whereby it must be made clear which in which contexts the addressing, appropriation and subversion takes place: why, for example, should certain subject norms at all unfold power effects on certain addressees? It is therefore necessary to clarify whether there are specific institutional, organizational or life-world contexts in which subject positions are processed and specific individuals or collectives are addressed. In the empirical studies presented in the third chapter, subject positions were mediated in school or in the context of the work place, but it not always known at the beginning of the research process which subject positions are imposed by whom or which subject positions people relate to. These relations of subject positions and self-positioning therefore cannot be presupposed. Instead, they have to be analyzed in a tentative and circular research process using qualitative methods. Hence, the ISA approach requires combining discursive or ethnographic data with methods of focus groups, biographical interviews or methods of qualitative interviews.
The focus on discourses and the subject positions in the ISA takes into account the fact that in the present almost all aspects of human life are 'surrounded' by discourse (Clarke 2005, p. 145). Considering the increasing medialization of society, the numerous 'experts' who distribute their politics of knowledge in an endlessly growing number guidebooks and self-help literature, video tutorials on social media platforms and various internet blogs on health, partnership, sexuality, beauty etc. and considering the numerous movies and TV productions in which e.g. gender stereotypes and narratives of idealized partnerships circulate and so on, analyzing discourses and subject positions becomes a crucial factor because of their omnipresence in contemporary life. However, people are not only shaped and influenced by discourses but also by biographical events, neighborhoods, social classes, professional roles and socially constructed categories like ethnicity, political convictions or sexual preferences that are adopted or experience in the context of the life-world. Therefore the ISA's concept of self-positioning is a heuristic tool to examine if and how life-world or organizationa contexts are mediated through discursively constructed subject positions and if and how they are adapted, opposed, ignored, enforced or re-signified.

This methodological perspective based on Butler, Foucault and the Interpretative Paradigm integrates the decentered subject into empirical research and adopts qualitative methods in order to establish a broader perspective on the discursive situatedness of human subjectivity. This kind of subjectivation research does not understand the human individual as the center of meaning making and an absolutely free individual in an empathic sense nor does it imply a fully determined actor. Instead, the goal of the ISA is to examine power relations and agency empirically and to analyze how people are addressed in specific contexts and if they are able to act and think differently. Therefore, the ISA is a critical research program that reveals the contingency of normative orders and the restrictions that people experience in specific situations.

FUNDING: This research received no external funding.

CONFLICTS OF INTEREST: The author declares no conflict of interest.

\section{REFERENCES}

Althusser, Louis. 2001. Lenin and Philosophy and other Essays. New York: Monthly Review Press.

Berger, Peter L. and Thomas Luckmann. 1991. The Social Construction of Reality. A Treatise in the Sociology of Knowledge. London \& New York: Penguin Books. [1966]

Boltanski, Luc and Eve Chiapello. 2005. The New Spirit of Capitalism. London and New York, Verso.

Bosančić, Saša. 2017. Arbeiter ohne Eigenschaften. Über die Subjektivierungsweisen angelernter Arbeiter. Wiesbaden: Springer VS.

Bosančić, Saša. 2017. "Selbst-Positionierung zwischen Reflexivität, Eigen-Sinn und Transformation - die Forschungsperspektive der Interpretativen Subjektivierungsanalyse." in Geschlossene Gesellschaften. Verhandlungen des 38. Kongresses 
der Deutschen Gesellschaft für Soziologie in Bamberg 2016, edited by S. Lessenich, http://publikationen.soziologie.de/index.php/kongressband 2016.

Bosančić, Saša. 2018a. "Die Forschungsperspektive der Interpretativen Subjektivierungsanalyse." Pp. 43-65 in Subjekt und Subjektivierung. Empirische und theoretische Perspektiven auf Subjektivierungsprozesse, edited by A. Geimer, S. Amling and S. Bosančić. Wiesbaden: Springer VS.

Bosančić, Saša. 2018b. "Self-positioning of semi-skilled workers. Analysing subjectification processes with SKAD.” Pp. 186-201 in The Sociology of Knowledge Approach to Discourse. Investigating the Politics of Knowledge and Meaning-making, edited by R. Keller, A.-K. Hornidge and W. J. Schünemann. London \& New York: Routledge.

Bröckling, Ulrich. 2015. The Entreprenurial Self. Fabricating a New Type of Subject. London: SAGE.

Burchell, Graham, Colin Gordon \& Peter Miller, eds. 1991. The Foucault Effect: Studies in Governmentality. Hemel Hampstead: Harvester Wheatsheaf.

Butler, Judith. 1997. The Psychic Life of Power. Theories of Subjection. Stanford: Stanford University Press.

Butler, Judith. 2011. Bodies that matter. London and New York: Routledge. [1993]

Clarke, Adele E. 2005. Situational Analysis: Grounded Theory After the Postmodern Turn. Thousand Oaks: SAGE.

Dean, Mitchell. 1999. Governmentality: Power and Rule in Modern Society. London: SAGE.

Foucault, Michel. 1988: “Technologies of the Self.” in Technologies of the Self. A seminar with Michel Foucault, edited by L. H. Martin et al. Amherst: University of Massachusetts Press.

Foucault, Michel. 1990a. The History of Sexuality. Volume 1: An Introduction. New York: Pantheon.

Foucault, Michel. 1990b. The Use of Pleasure. Volume 2 of The History of Sexuality. New York: Pantheon.

Foucault, Michel. 1994. “The subject and power.” Pp. 326-348 in Michel Foucault. Power, edited by J. Faubion. New York: The New Press.

Foucault, Michel. 1995. Discipline and Punish. The Birth of the Prison. New York, Vintage Books. [1975]

Foucault, Michel. 2003. Abnormal: Lectures at the Collège de France, 1974-1975. London: Verso.

Foucault, Michel. 2007. Security, Territory, Population: Lectures at the Collège de France, 1977-1978. Basingstoke: Palgrave Macmillan.

Foucault, Michel. 2008. The Birth of Biopolitics: Lectures at the Collège de France, 1978-1979. Basingstoke: Palgrave Macmillan.

Giddens, Anthony. 1984. The Constitution of Society: Outline of the Theory of Structuration. Berkeley: UCLA Press.

Goffman, Erving. 1961. Asylums. Essays on the Social Situation of Mental Patients and Other Inmates. Graden City and New York: Anchor Books.

Goffman, Erving. 1971. Relations in Public. Microstudies of the Public Order. New York:
Basic Books.

Goffman, Erving. 1974. Frame Analysis. An Essay on the Organization of Experience. New York et al.: Harper Colophon Books.

Goffman, Erving. 1986. Stigma. Notes on the Management of Spoiled Identity. New York: Touchstone [1963]

Goffman, Erving. 2013. Encounters. Two Studies in the Sociology of Interaction. Mansfield Centre: Martino Publishing [1961]

Keller, Reiner and Ann-Kathrina Hornidge \& Wolf J. Schünemann, eds. 2018. The Sociology of Knowledge Approach to Discourse. Investigating the Politics of Knowledge and Meaning-Making. London \& New York: Routledge.

Keller, Reiner. 2011. "The Sociology of Knowledge Approach to Discourse (SKAD)." Human Studies 34(1): 43-65.

Keller, Reiner. 2013. Doing Discourse Research. An Introduction for Social Scientists. London and Thousand Oaks: SAGE.

Keller, Reiner. 2018. "The sociology of knowledge approach to discourse: an introduction.” Pp. 16-47 in The Sociology of Knowledge Approach to Discourse. Investigating the Politics of Knowledge and Meaning-Making, edited by R. Keller, A.-K. Hornidge \& W. J. Schünemann. London \& New York: Routledge.

Lemke, Thomas. 2001. "The Birth of Biopolitics: Michel Foucault's Lecture at the Collège de France." Economy and Society 30(2): 190-209.

Mead, Georg Herbert. 1972. Mind, Self, and Society. From the Standpoint of a Social Behaviorist. Chicago: The University of Chicago Press. [1934]

Mills, Charles W. 1940. Situated Actions and Vocabularies of Motive. In: American Sociological Review 5(6), pp. 904-913.

Pfahl, Lisa and Justin J. W. Powell. 2011. “Legitimating School Segregation. The Special Education Profession and the Discourse of Learning Disability in Germany, 19082008." Disability \& Society 26(2): 449-462.

Pfahl, Lisa. 2011. Techniken der Behinderung. Der deutsche Lernbehinderungsdiskurs, die Sonderschule und ihre Auswirkungen auf Bildungsbiografien. Bielefeld: transcript.

Reichertz, Jo. 2013. Hermeneutic Sociology of Knowledge, in: Arbor, 189 (761), a036. DOI: http://dx.doi.org/10.3989/arbor.2013.761n3004

Rose, Nikolas. 2007. The Politics of Life Itself: Biomedicine, Power, and Subjectivity in the Twenty-first Century. Princeton, NJ: Princeton University Press.

Schütz, Alfred and Thomas Luckmann. 1973. Structures of the Life-World, Volume I. Evanstone, Northwestern University Press.

Spivak, Gayatri Chakravorty. 1988. “Can subalterns speak?” Pp. 271-315 in Marxism and the Interpretation of Culture, edited by L. Grossberg and N. Carry. Champaign: University of Illinois Press, pp. 271-315.

Strauss, Anselm L. 1959. Mirrors and Masks: The Search for Identity. Glencoe: The Free Press of Glencoe.

Weber, Max. 2002. The Protestant Ethic and the 'Spirit of Capitalism' and other writings. London: Penguin. [1904/1905 


\section{BIOGRAPHICAL NOTE}

Saša Bosančić is senior researcher at the University of Augsburg, Germany.

OPEN ACCESS: This article is distributed under the terms of the Creative Commons Attribution Noncommercial License (CC BY-NC 4.0) which permits any noncommercial use, and reproduction in any medium, provided the original author(s) and source are credited. 